\section{Evaluation of the U.S. Mothbean Collection for Seed Yield Potential in Virginia and Nutritional Composition of Freshly Harvested Seed}

\author{
Harbans L. Bhardwaj ${ }^{1}$ and Anwar A. Hamama
}

ADDITIONAL INDEX WORDS. new crops, food legumes, protein, micronutrients, macronutrients

SUMMARY. Even though mothbean (Vigna aconitifolia), a drought- and heattolerant crop, may have potential in the eastern United States, information about its production in this region is not available. To characterize potential seed yields and preliminary nutritional quality, 54 accessions were grown near Petersburg, VA, during 2011, 2012, and 2013. The seed yields varied from 48 to $413 \mathrm{lb} /$ acre. The mean concentrations of protein, calcium, iron, and zinc in mature mothbean seed were $21.9 \%, 0.17 \%, 64.8 \mathrm{ppm}$, and $37.5 \mathrm{ppm}$, respectively. These values compared well with those in mungbean (Vigna radiata) and tepary bean (Phaseolus acutifolius). The results demonstrated that mothbean has considerable potential as an alternative, new food legume crop in Virginia and eastern United States.

$\mathrm{M}$ othbean is known to be a drought- and heat-tolerant legume crop (Manga et al., 2015). It is also known by other common names, such as mat bean, matki bean, mout bean, or dew gram (Stephens, 1994). The name "moth" comes from the Hindi word pronounced "mat" or "mote" according to the National Academy of Sciences (NAS, 1979). Mothbean is popular pulse crop in India. It has been tried for cattle forage in Texas and California and has shown promise (Stephens, 1994).

In many parts of the world, there is increasing scarcity of water for agriculture (Jury and Vaux, 2007). Consequently, there is potential for the use of drought-tolerant legumes in agriculture not only for their symbiotic nitrogen $(\mathrm{N})$ fixation potential but also for reduced water use. Mothbean is a hot weather, droughtresistant legume. Although mothbean is a short-day plant, Stephens (1994) indicated that climatic requirements of mothbean are similar to those for cowpea (Vigna unguiculata). It could be grown in the spring and fall seasons in most of Florida, and in the winter in southern Florida. When seeded in early September in

Agricultural Research Station, Virginia State University, Petersburg, VA 23806

Use of trade names or vendors does not imply an endorsement of the products named or criticism of similar ones not named.

${ }^{1}$ Corresponding author. E-mail: hbhardwaj@vsu.edu. doi: 10.21273/HORTTECH03432-16
Gainesville, FL, fair pod production was achieved by late November (Stephens, 1994). The National Academy of Sciences (1979) indicated that mothbean could substantially increase the food or forage available to arid and semiarid lands throughout the tropics, subtropics, and even some warm-temperate areas and that it is the most drought-tolerant pulse crop. Mothbean hay is readily eaten by livestock and has a feeding value almost equal to that of alfalfa (Medicago sativa) hay (NAS, 1979). U.S. Department of Agriculture, Agricultural Research Service (USDA-ARS), currently maintains a collection of 56 mothbean accessions.
Based on our desire to diversify cropping system, we are interested in several crops related to mungbean and mothbean since such crops have been observed to have great potential as supplemental or alternate sources of legume protein (Fery, 2002). Most of these crops are known to be heat and drought tolerant and have potential for introduction in the United States for increased production. It has been observed that introduction of these crops can create new opportunities and provide alternative crops for American farmers. These crops can also provide American consumers access to new and novel foods.

Given that mothbean is known to be adapted to hot, dry climates and no information is available on its production potential in the eastern United States, the objective of this study was to characterize variation among 54 accessions from the USDA-ARS collection for potential seed yield and nutritional quality when grown in the eastern United States.

\section{Materials and methods}

For this study, 54 accessions from mothbean collection of USDA-ARS maintained at Southern Plant Introduction Station (Griffin, GA) were used. These accessions were grown during 2011, 2012, and 2013 at Virginia State University's Randolph Farm near Petersburg, VA (lat. $37^{\circ} 15^{\prime} \mathrm{N}$, long. $\left.77^{\circ} 31^{\prime} \mathrm{W}\right)$. Planting dates were 26

Table 1. Analysis of variance for effects of accessions and years on seed yields of mothbean grown at Petersburg, VA, during 2011, 2012, and 2013.

\begin{tabular}{lcc}
\hline Source & Mean squares & Significance of mean squares $^{\mathbf{z}}$ \\
\hline Replication (year) & 5,342 & Ns \\
Year & 361,187 & $* *$ \\
Accession & 31,594 & $* *$ \\
Error (year $\times$ accession) & 15,724 & - \\
\hline
\end{tabular}

Ns, * ${ }^{*}$ Nonsignificant or significant at $5 \%$, and significant at $1 \%$ levels, respectively.

\begin{tabular}{llll}
\hline $\begin{array}{l}\text { Units } \\
\begin{array}{l}\text { To convert U.S. to SI, } \\
\text { multiply by }\end{array}\end{array}$ & U.S. unit & SI unit & $\begin{array}{l}\text { To convert SI to U.S., } \\
\text { multiply by }\end{array}$ \\
\hline 0.0731 & $\mathrm{fl} \mathrm{oz} / \mathrm{acre}$ & $\mathrm{L} \cdot \mathrm{ha}^{-1}$ & 13.6840 \\
0.3048 & $\mathrm{ft}$ & $\mathrm{m}$ & 3.2808 \\
2.54 & inch $(\mathrm{es})$ & $\mathrm{cm}$ & 0.3937 \\
25.4 & inch $(\mathrm{es})$ & $\mathrm{mm}$ & 0.0394 \\
1.1209 & lb/acre & $\mathrm{kg} \cdot \mathrm{ha}^{-1}$ & 0.8922 \\
28.3495 & $\mathrm{oz}$ & $\mathrm{g}$ & 0.0353 \\
1 & $\mathrm{ppm}$ & $\mathrm{mg} \cdot \mathrm{kg}^{-1}$ & 1 \\
$\left({ }^{\circ} \mathrm{F}-32\right) \div 1.8$ & $\mathrm{o} F$ & ${ }^{\circ} \mathrm{C}$ & $\left({ }^{\circ} \mathrm{C} \times 1.8\right)+32$
\end{tabular}


Table 2. Seed yields of 54 mothbean accessions during 2011, 2012, 2013, and 3 -year mean when grown at Petersburg, VA.

\begin{tabular}{|c|c|c|c|c|c|c|}
\hline \multirow[b]{2}{*}{ Code } & 2011 & 2012 & 2013 & \multirow[b]{2}{*}{ Mean } & \multirow[b]{2}{*}{ Accession } & \multirow[b]{2}{*}{ Origin } \\
\hline & \multicolumn{3}{|c|}{ Seed yield $(\mathrm{g} / \text { row })^{\mathrm{z}}$} & & & \\
\hline 1 & $83 c-m^{y}$ & $85 b-n$ & $141 \mathrm{a}$ & $103 \mathrm{a}-\mathrm{i}$ & Grifl 545 & United States \\
\hline 2 & $26 \mathrm{~m}-\mathrm{p}$ & $39 \mathrm{j}-\mathrm{p}$ & $46 \mathrm{a}$ & $38 \mathrm{i}-\mathrm{k}$ & PI-164419 & India \\
\hline 3 & $92 \mathrm{~b}-\mathrm{k}$ & $102 \mathrm{a}-\mathrm{h}$ & $127 \mathrm{a}$ & $110 \mathrm{a}-\mathrm{h}$ & PI-164444 & India \\
\hline 4 & $158 \mathrm{ab}$ & $10 \mathrm{p}$ & $179 \mathrm{a}$ & $89 \mathrm{~b}-\mathrm{k}$ & PI- 164530 & India \\
\hline 5 & $77 \mathrm{c}-\mathrm{O}$ & $143 \mathrm{ab}$ & $96 \mathrm{a}$ & $115 \mathrm{a}-\mathrm{f}$ & PI-165479 & India \\
\hline 6 & $120 \mathrm{a}-\mathrm{f}$ & $111 \mathrm{a}-\mathrm{f}$ & $125 \mathrm{a}$ & $119 \mathrm{a}-\mathrm{e}$ & PI- 165482 & India \\
\hline 7 & $61 \mathrm{~g}-\mathrm{p}$ & $55 \mathrm{f}-\mathrm{p}$ & $68 \mathrm{a}$ & $61 \mathrm{c}-\mathrm{k}$ & PI-173931 & India \\
\hline 8 & $88 \mathrm{c}-1$ & $92 a-1$ & $202 \mathrm{a}$ & 119 a-e & PI-182976 & India \\
\hline 9 & $341-p$ & $51 \mathrm{~g}-\mathrm{p}$ & $68 \mathrm{a}$ & $51 \mathrm{e}-\mathrm{k}$ & PI-213013 & India \\
\hline 10 & $10 \mathrm{p}$ & $12 \mathrm{p}$ & $43 \mathrm{a}$ & $19 \mathrm{k}$ & PI-213014 & India \\
\hline 11 & $40 j-p$ & $49 \mathrm{~g}-\mathrm{p}$ & $68 \mathrm{a}$ & $56 \mathrm{~d}-\mathrm{k}$ & PI-214332 & India \\
\hline 12 & $92 \mathrm{c}-\mathrm{k}$ & $129 \mathrm{a}-\mathrm{d}$ & $48 \mathrm{a}$ & 89 b-k & PI-214333 & India \\
\hline 13 & $70 \mathrm{e}-\mathrm{p}$ & $68 \mathrm{e}-\mathrm{p}$ & $85 a$ & $75 \mathrm{~b}-\mathrm{k}$ & PI-215648 & India \\
\hline 14 & $116 a-f$ & $107 \mathrm{a}-\mathrm{g}$ & $110 \mathrm{a}$ & $110 \mathrm{a}-\mathrm{h}$ & PI-215649 & India \\
\hline 15 & $99 a-j$ & $75 \mathrm{~d}-\mathrm{O}$ & $132 \mathrm{a}$ & $103 \mathrm{a}-\mathrm{i}$ & PI-216038 & India \\
\hline 16 & $27 \mathrm{~m}-\mathrm{p}$ & $26 n-p$ & $41 \mathrm{a}$ & 30 j-k & PI-218101 & Pakistan \\
\hline 17 & $40 j-p$ & $55 \mathrm{f}-\mathrm{p}$ & $137 \mathrm{a}$ & $72 \mathrm{~b}-\mathrm{k}$ & PI-218102 & Pakistan \\
\hline 18 & $63 \mathrm{f}-\mathrm{p}$ & $45 \mathrm{~h}-\mathrm{p}$ & $88 \mathrm{a}$ & $66 \mathrm{~b}-\mathrm{k}$ & PI-223521 & Afghanistan \\
\hline 19 & $40 j-p$ & $51 \mathrm{~g}-\mathrm{p}$ & $99 \mathrm{a}$ & $68 \mathrm{~b}-\mathrm{k}$ & PI-223801 & Afghanistan \\
\hline 20 & $69 \mathrm{e}-\mathrm{p}$ & $56 \mathrm{f}-\mathrm{p}$ & $115 \mathrm{a}$ & $80 \mathrm{~b}-\mathrm{k}$ & PI-271399 & India \\
\hline 21 & $101 \mathrm{a}-\mathrm{i}$ & $93 \mathrm{a}-\mathrm{k}$ & $184 \mathrm{a}$ & $131 \mathrm{a}-\mathrm{c}$ & PI-271400 & India \\
\hline 22 & $26 \mathrm{~m}-\mathrm{p}$ & $44 \mathrm{i}-\mathrm{p}$ & $75 \mathrm{a}$ & $53 \mathrm{~d}-\mathrm{k}$ & PI-271488 & India \\
\hline 23 & $85 \mathrm{c}-\mathrm{m}$ & $79 \mathrm{~d}-\mathrm{O}$ & $159 \mathrm{a}$ & $112 \mathrm{a}-\mathrm{h}$ & PI-271489 & India \\
\hline 24 & $24 \mathrm{n}-\mathrm{p}$ & $37 \mathrm{j}-\mathrm{p}$ & $88 \mathrm{a}$ & $42 \mathrm{~h}-\mathrm{k}$ & PI-288577 & India \\
\hline 25 & $48 \mathrm{i}-\mathrm{p}$ & $40 j-p$ & $129 \mathrm{a}$ & 77 b-k & PI-288578 & India \\
\hline 26 & $321-p$ & $31 \mathrm{~m}-\mathrm{p}$ & $59 \mathrm{a}$ & $42 \mathrm{~h}-\mathrm{k}$ & PI-288579 & India \\
\hline 27 & $91 \mathrm{c}-1$ & $87 b-m$ & $146 \mathrm{a}$ & $111 \mathrm{a}-\mathrm{h}$ & PI-288580 & India \\
\hline 28 & $23 \mathrm{o}-\mathrm{p}$ & $56 \mathrm{f}-\mathrm{p}$ & $41 \mathrm{a}$ & $44 \mathrm{~g}-\mathrm{k}$ & PI-288581 & India \\
\hline 29 & $140 \mathrm{abc}$ & $104 \mathrm{a}-\mathrm{h}$ & $165 \mathrm{a}$ & $136 \mathrm{ab}$ & PI-288582 & India \\
\hline 30 & 34 l-p & $35 \mathrm{k}-\mathrm{p}$ & $107 \mathrm{a}$ & 64 b-k & PI-288583 & India \\
\hline 31 & $49 \mathrm{i}-\mathrm{p}$ & $54 \mathrm{f}-\mathrm{p}$ & $109 \mathrm{a}$ & 75 b-k & PI-288584 & India \\
\hline 32 & $131 \mathrm{a}-\mathrm{e}$ & $123 \mathrm{a}-\mathrm{e}$ & $119 \mathrm{a}$ & $123 \mathrm{a}-\mathrm{d}$ & PI-288804 & India \\
\hline 33 & $67 \mathrm{f}-\mathrm{p}$ & $52 \mathrm{f}-\mathrm{p}$ & $143 \mathrm{a}$ & $92 \mathrm{~b}-\mathrm{j}$ & PI-288805 & India \\
\hline 34 & $80 \mathrm{c}-\mathrm{O}$ & $89 \mathrm{~b}-\mathrm{m}$ & $116 a$ & $98 \mathrm{a}-\mathrm{j}$ & PI-288808 & India \\
\hline 35 & $162 \mathrm{a}$ & $148 \mathrm{a}$ & $187 \mathrm{a}$ & $167 \mathrm{a}$ & PI-288809 & India \\
\hline 36 & $124 \mathrm{a}-\mathrm{f}$ & $126 \mathrm{a}-\mathrm{e}$ & $145 \mathrm{a}$ & $133 a-c$ & PI-288810 & India \\
\hline 37 & $48 \mathrm{i}-\mathrm{p}$ & $331-\mathrm{p}$ & $119 \mathrm{a}$ & $71 \mathrm{~b}-\mathrm{k}$ & PI-288811 & India \\
\hline 38 & $76 \mathrm{~d}-\mathrm{O}$ & $93 a-1$ & $125 \mathrm{a}$ & $102 \mathrm{a}-\mathrm{i}$ & PI-288812 & India \\
\hline 39 & $43 \mathrm{i}-\mathrm{p}$ & $50 \mathrm{~g}-\mathrm{p}$ & $113 \mathrm{a}$ & 74 b-k & PI-288813 & India \\
\hline 40 & $40 j-p$ & $20 \mathrm{p}$ & $185 \mathrm{a}$ & $90 \mathrm{~b}-\mathrm{k}$ & PI-288814 & India \\
\hline 41 & $93 \mathrm{~b}-\mathrm{k}$ & $80 \mathrm{~d}-\mathrm{O}$ & $112 \mathrm{a}$ & 96 b-j & PI-288815 & India \\
\hline 42 & $72 \mathrm{e}-\mathrm{O}$ & $101 \mathrm{a}-\mathrm{i}$ & $121 \mathrm{a}$ & $103 a-i$ & PI-288816 & India \\
\hline 43 & $61 \mathrm{~g}-\mathrm{p}$ & $74 \mathrm{~d}-\mathrm{O}$ & $146 \mathrm{a}$ & $100 a-j$ & PI-288817 & India \\
\hline 44 & $55 \mathrm{~h}-\mathrm{p}$ & $37 \mathrm{j}-\mathrm{p}$ & $51 \mathrm{a}$ & $46 \mathrm{f}-\mathrm{k}$ & PI-360948 & India \\
\hline 45 & $139 \mathrm{a}-\mathrm{d}$ & $141 \mathrm{abc}$ & $19 \mathrm{a}$ & $132 a-c$ & PI-365427 & Pakistan \\
\hline 46 & $22 \mathrm{o}-\mathrm{p}$ & $52 \mathrm{f}-\mathrm{p}$ & $42 \mathrm{a}$ & $42 \mathrm{~h}-\mathrm{k}$ & PI-372355 & Yemen \\
\hline 47 & $41 \mathrm{i}-\mathrm{p}$ & $83 c-n$ & $83 a$ & $74 \mathrm{~b}-\mathrm{k}$ & PI-426976 & Pakistan \\
\hline 48 & $63 \mathrm{f}-\mathrm{p}$ & $59 \mathrm{f}-\mathrm{p}$ & $99 \mathrm{a}$ & $76 \mathrm{~b}-\mathrm{k}$ & PI-426977 & Pakistan \\
\hline 49 & $67 f-p$ & $96 a-j$ & $110 \mathrm{a}$ & $96 a-j$ & PI-426978 & Pakistan \\
\hline 50 & $71 \mathrm{e}-\mathrm{O}$ & $80 \mathrm{~d}-\mathrm{O}$ & $174 \mathrm{a}$ & $116 \mathrm{a}-\mathrm{f}$ & PI-426979 & Pakistan \\
\hline 51 & $66 f-p$ & $73 \mathrm{o}-\mathrm{p}$ & $112 \mathrm{a}$ & 84 b-k & PI-426980 & Pakistan \\
\hline 52 & $77 \mathrm{c}-\mathrm{O}$ & $63 \mathrm{f}-\mathrm{p}$ & $110 \mathrm{a}$ & $85 \mathrm{~b}-\mathrm{k}$ & PI-426981 & Pakistan \\
\hline 53 & $80 c-0$ & $105 \mathrm{a}-\mathrm{h}$ & $161 \mathrm{a}$ & $123 \mathrm{a}-\mathrm{e}$ & PI-426982 & Pakistan \\
\hline 54 & $93 \mathrm{~b}-\mathrm{k}$ & $84 c-n$ & $148 \mathrm{a}$ & $111 \mathrm{a}-\mathrm{h}$ & PI-426983 & Pakistan \\
\hline
\end{tabular}

${ }^{{ }^{2}}$ Seed yields averaged over two replications; $1 \mathrm{~g}$ per $4 \times 10-\mathrm{ft}(1.22 \times 3.05 \mathrm{~m})$ row $=2.4008 \mathrm{lb} / \mathrm{acre}=2.6910$ $\mathrm{kg} \cdot \mathrm{ha}^{-1}$.

${ }^{y}$ Means followed by similar letters were not different according to Duncan's multiple range test at $P \leq 0.05$.
June 2011, 21 June 2012, and 19 May 2013. During 2011, seeds received from Southern Plant Introduction Station were used. However, seeds harvested from previous crops were used for plantings during 2012 and 2013.

The experiment each year was designed as a randomized complete block design with two replications. Each plot consisted of a single row spaced $4 \mathrm{ft}$ apart. The rows were $10 \mathrm{ft}$ long. About 100 seeds were planted in each row with a tractor-driven research planter (Almaco, Nevada, IA). This seed rate is similar to that used in the past for several legume crops such as mungbean. The seed depth was $\approx l$ inch. The final population was $\approx 6$ plants $/ \mathrm{ft}$. These plots received $405 \mathrm{lb} /$ acre of $10 \mathrm{~N}-4.4 \mathrm{P}-8.3 \mathrm{~K}$ fertilizer. The fertilizer did not contain any micronutrients and was applied about a month after planting.

The soil type was Abel sandy loam (fine loamy, mixed, thermic Aquatic Hapludult). Experimental area received a preplant incorporated treatment of trifluralin herbicide (Treflan 4EC; DowElanco, Indianapolis, IN) at the rate of $15 \mathrm{fl} \mathrm{oz} /$ acre of active ingredient. The plots were manually weeded once. All plots were harvested at maturity by hand and threshed using a stationary thresher and data on seed yields were recorded. Harvest dates were 28 Oct. 2011, 6 Nov. 2012, and 11 Nov. 2013.

Chemical composition of mothbean seeds, produced during 2013, was determined by a commercial laboratory (A\&L Agricultural Laboratory, Richmond, VA) according to AOAC standard methods (AOAC, $1995)$. Protein concentration was calculated as $\mathrm{N} \times 6.25$. These analyses were only conducted with seed produced during 2013. All data were analyzed using the analysis of variance (ANOVA) procedures in SAS (version 9.4; SAS Institute, Cary, NC). Means were separated using Duncan's multiple range test at the $5 \%$ level of significance.

\section{Results and discussion}

ANOVA indicated that year and accession effects on mothbean seed yield were highly significant (Table 1). The mean squares due to years were $\approx 13$ times greater than those due to accessions indicating that the growing environment has a pronounced effect on mothbean seed yield. 
Results of this study demonstrated availability of considerable variation for seed yield in 54 mothbean accessions (Table 1). Single row seed yields, averaged over 3 years, varied from 166.6 to $19.5 \mathrm{~g} /$ row Based on plot size of $10 \times 4 \mathrm{ft}$, these seed yields correspond to 48 to $413 \mathrm{lb} /$ acre, respectively. ANOVA indicated that variation among 54 accessions was significant at the $1 \%$ level. A significant difference (1\% level) also existed among years, mean seed yields for 2011 (71 g/row) and $2012(72 \mathrm{~g} / \mathrm{row})$ were not significantly different while mean seed yield during 2013 (115 g/row) was significantly superior to those of 2011 and 2012 years. The interaction between accessions and years was not significant. The highest mean yields were 115,72 , and

Table 3. Air temperature and rainfall data for Petersburg, VA, during 2011, 2012 , and 2013.

\begin{tabular}{llcllccc}
\hline & \multicolumn{3}{c}{ Air temp $\left({ }^{\circ} \mathbf{F}\right)^{\mathrm{z}}$} & & \multicolumn{3}{c}{ Rainfall (inches) $^{\mathrm{z}}$} \\
\cline { 2 - 4 } \cline { 6 - 8 } Month & $\mathbf{2 0 1 1}$ & $\mathbf{2 0 1 2}$ & $\mathbf{2 0 1 3}$ & & $\mathbf{2 0 1 1}$ & $\mathbf{2 0 1 2}$ & $\mathbf{2 0 1 3}$ \\
\hline May & 69 & 71 & 66 & & 1.93 & 3.07 & 2.60 \\
June & 77 & 74 & 76 & & 2.20 & 1.01 & 3.78 \\
July & 81 & 84 & 80 & 2.97 & 6.74 & 0.00 \\
August & 79 & 78 & 77 & & 3.94 & 2.51 & 0.67 \\
September & 74 & 69 & 71 & & 4.99 & 5.90 & 0.00 \\
October & 60 & 60 & 63 & & 3.02 & 3.19 & 0.00 \\
Mean & 73.3 & 72.7 & 72.2 & & 3.10 & 3.70 & 1.10 \\
\hline
\end{tabular}

${ }^{\mathrm{z}}\left({ }^{\circ} \mathrm{F}-32\right) \div 1.8={ }^{\circ} \mathrm{C}, \mathrm{l}$ inch $=25.4 \mathrm{~mm}$.

$71 \mathrm{~g} /$ row for 2011,2012 , and 2013 , respectively.

The seed yields during 2011, 2012 , and 2013 varied from 10 to 162,10 to 148 , and 41 to $202 \mathrm{~g} /$ row, respectively (Table 2). Significant variation existed among 54 lines within 2011 and 2012 for seed yields, whereas the seed yields of 54 lines during 2013 were not significantly different. The five best lines for seed yield during 2011 were PI-288809, PI-164530, PI-288582, PI-365427, and PI-288804 with respective yields being $162,158,140,139$, and $131 \mathrm{~g} /$ row. The five best lines for seed yield during 2012 were PI-288809, PI165479, PI-365427, PI-214333, and PI-288810 with respective yields being $148,143,141,129$, and $126 \mathrm{~g}$ /row. The five best lines for seed yield during 2013 were PI-182976, PI-288809, PI-288814, PI-271400, and PI164530 with respective seed yields being $202,187,185,184$, and 179

Table 4. Nutritional quality traits of mothbean accessions, grown during 2013 at Petersburg, VA.

\begin{tabular}{|c|c|c|c|c|c|c|c|c|c|c|c|}
\hline \multirow[b]{2}{*}{ Code $^{z}$} & \multirow[b]{2}{*}{ Protein } & $P^{y}$ & $\mathbf{K}$ & $S$ & $\mathrm{Ca}$ & Mg & $\mathrm{Fe}$ & Mn & $\mathrm{Cu}$ & $\mathrm{Zn}$ & B \\
\hline & & \multicolumn{5}{|c|}{$(\%)$} & \multicolumn{5}{|c|}{$(\mathrm{ppm})^{\mathrm{x}}$} \\
\hline 1 & 22.9 & 0.30 & 1.25 & 0.18 & 0.18 & 0.21 & 64.2 & 19.9 & 8.60 & 38.5 & 9.20 \\
\hline 4 & 23.4 & 0.29 & 1.33 & 0.18 & 0.18 & 0.21 & 63.2 & 21.4 & 9.30 & 37.7 & 7.80 \\
\hline 8 & 23.7 & 0.27 & 1.30 & 0.17 & 0.18 & 0.19 & 70.9 & 23.3 & 8.30 & 36.5 & 7.30 \\
\hline 14 & 22.8 & 0.29 & 1.37 & 0.18 & 0.18 & 0.23 & 79.3 & 31.8 & 8.60 & 38.8 & 8.90 \\
\hline 20 & 22.2 & 0.26 & 1.17 & 0.19 & 0.15 & 0.20 & 58.8 & 16.3 & 7.30 & 33.7 & 6.50 \\
\hline 21 & 22.1 & 0.28 & 1.27 & 0.19 & 0.15 & 0.20 & 60.9 & 18.3 & 7.85 & 35.8 & 6.50 \\
\hline 23 & 20.9 & 0.30 & 1.30 & 0.20 & 0.16 & 0.22 & 62.6 & 53.5 & 8.50 & 37.2 & 6.20 \\
\hline 27 & 19.9 & 0.30 & 1.31 & 0.18 & 0.15 & 0.22 & 60.0 & 23.3 & 7.90 & 36.5 & 7.00 \\
\hline 29 & 20.4 & 0.30 & 1.31 & 0.19 & 0.16 & 0.22 & 61.3 & 38.4 & 8.20 & 36.8 & 6.60 \\
\hline 30 & 23.7 & 0.30 & 1.32 & 0.19 & 0.16 & 0.20 & 62.9 & 41.5 & 7.50 & 37.9 & 5.60 \\
\hline 36 & 23.3 & 0.28 & 1.23 & 0.18 & 0.19 & 0.22 & 69.3 & 27.7 & 9.20 & 42.9 & 6.60 \\
\hline 37 & 22.9 & 0.30 & 1.33 & 0.18 & 0.16 & 0.22 & 61.0 & 19.7 & 9.90 & 40.0 & 6.50 \\
\hline 38 & 23.7 & 0.30 & 1.29 & 0.18 & 0.20 & 0.22 & 70.1 & 21.3 & 9.20 & 41.6 & 8.70 \\
\hline 39 & 21.2 & 0.26 & 1.29 & 0.18 & 0.17 & 0.20 & 67.7 & 23.2 & 8.70 & 35.4 & 4.80 \\
\hline 40 & 20.7 & 0.25 & 1.21 & 0.18 & 0.15 & 0.20 & 59.2 & 16.3 & 7.20 & 34.8 & 5.80 \\
\hline 41 & 20.0 & 0.28 & 1.29 & 0.18 & 0.18 & 0.23 & 60.8 & 21.4 & 8.10 & 36.0 & 8.80 \\
\hline 42 & 18.9 & 0.27 & 1.31 & 0.18 & 0.18 & 0.23 & 71.0 & 18.6 & 9.40 & 38.1 & 7.80 \\
\hline 43 & 19.1 & 0.29 & 1.40 & 0.18 & 0.18 & 0.25 & 64.9 & 20.0 & 8.10 & 38.6 & 6.00 \\
\hline 45 & 19.7 & 0.28 & 1.37 & 0.17 & 0.16 & 0.20 & 63.2 & 17.0 & 8.10 & 37.5 & 6.30 \\
\hline 49 & 23.4 & 0.33 & 1.41 & 0.19 & 0.17 & 0.21 & 66.2 & 19.3 & 8.40 & 37.5 & 7.30 \\
\hline 50 & 22.9 & 0.30 & 1.29 & 0.17 & 0.20 & 0.20 & 66.9 & 16.2 & 8.10 & 37.5 & 8.70 \\
\hline
\end{tabular}

${ }^{\mathrm{z}}$ Due to lack of sufficient seed, nutritional quality analyses were conducted only on 30 accessions. Code numbers in this column refer to accessions listed in Table 2 . ${ }^{y_{\mathrm{P}}}=$ phosphorus $\mathrm{K}=$ potassium $; \mathrm{S}=$ sulfur $\mathrm{Ca}=$ calcium $; \mathrm{Mg}=$ magnesium; $\mathrm{Fe}=$ iron; $\mathrm{Mn}=$ manganese $\mathrm{Cu}=\mathrm{copper} ; \mathrm{Zn}=$ zinc $; \mathrm{B}=$ boron.

${ }^{\mathrm{x}} \mathrm{l} \mathrm{ppm}=1 \mathrm{mg} \cdot \mathrm{kg}^{-1}$ 
Table 5. Nutritional quality traits of mothbean relative to two other food legumes averaged over 54 accessions grown during 2013 at Petersburg, VA.

\begin{tabular}{|c|c|c|c|c|}
\hline \multirow[b]{2}{*}{ Trait } & \multicolumn{2}{|c|}{ Mothbean } & \multirow[b]{2}{*}{ Tepary bean $^{z}$} & \multirow[b]{2}{*}{ Mungbean $^{\mathrm{y}}$} \\
\hline & Mean & Range & & \\
\hline Protein (\%) & 21.9 & $18.9-23.7$ & 23.9 & 24.3 \\
\hline \multicolumn{5}{|c|}{ Macronutrients (\%) } \\
\hline $\mathrm{P}^{\mathrm{x}}$ & 0.29 & $0.25-0.33$ & 0.451 & 0.481 \\
\hline $\mathrm{K}$ & 1.31 & $1.17-1.41$ & 1.531 & 1.353 \\
\hline S & 0.18 & $0.17-0.20$ & 0.311 & 0.208 \\
\hline $\mathrm{Ca}$ & 0.17 & $0.15-0.20$ & 1.84 & 1.45 \\
\hline $\mathrm{Mg}$ & 0.21 & $0.18-0.25$ & 0.192 & 0.184 \\
\hline \multicolumn{5}{|c|}{ Micronutrients $(\mathrm{ppm})^{\mathrm{x}}$} \\
\hline $\mathrm{Fe}$ & 64.8 & $58.8-79.3$ & 110 & 84.2 \\
\hline Mn & 23.9 & $13.5-53.5$ & 28 & 19.4 \\
\hline $\mathrm{Cu}$ & 8.38 & $7.20-9.90$ & 12 & 12.0 \\
\hline $\mathrm{Zn}$ & 37.5 & $33.7-42.9$ & 43 & 38.8 \\
\hline $\mathrm{B}$ & 7.27 & $4.80-11.5$ & 12 & 13.2 \\
\hline
\end{tabular}

${ }^{\mathrm{z}}$ Adapted from Bhardwaj and Hamama (2004). Tepary beans were produced at Virginia State University's Randolph Farm near Petersburg, VA, during 1997 and 1998.

yadapted from Bhardwaj and Hamama (2016). The mungbeans were produced in Virginia State University's Randolph Farm during 2012 and 2013.

${ }^{\mathrm{x}} \mathrm{P}=$ phosphorus; $\mathrm{K}=$ potassium $; \mathrm{S}=$ sulfur $; \mathrm{Ca}=$ calcium; $\mathrm{Mg}=$ magnesium $; \mathrm{Fe}=$ iron; $\mathrm{Mn}=$ manganese $; \mathrm{Cu}=$ copper; $\mathrm{Zn}=$ zinc; $\mathrm{B}=$ boron; $1 \mathrm{ppm}=1 \mathrm{mg} \cdot \mathrm{kg}^{-1}$.

$\mathrm{g} /$ row. Based on seed yields, averaged over 3 years, the five best lines for seed yield were PI-288809, PI-288582, PI288810, PI-365427, and PI-271400 with respective yields being 167,165 , 145,132 , and $131 \mathrm{~g} /$ row. Based on these results we identified PI-288809, PI-288582, and PI-288810 as the best three mothbean lines.

Based on weather data from Petersburg, VA, for the growing season (May-October), the 3 years were not considerably different for average monthly temperatures (Table 3). However, considerable differences existed among the 3 years for rainfall. The mean monthly precipitations at Petersburg, VA, respectively for the 6 months of growing period were 3.1 , 3.7 , and 1.1 inches during 2011, 2012 , and 2013, respectively. The 3 years were considerably different for total rainfall. The year 2013 received considerably less rainfall as compared with 2011 and 2012 indicating that mothbean may be more adapted to drought environments. However, this observation is confounded by the fact that 2013 experiments were planted at an earlier date than those in 2011 and 2012 but is supported by published results. In addition, month of June received more rainfall in 2013 as compared with 2011 and 2012. The plots in these studies were not irrigated.

The nutritional quality traits of 30 mothbean lines were determined only for the seed produced in 2013 and are presented in Table 4. Because of the lack of sufficient quantity of seed, nutritional quality analyses were conducted only on 30 accessions. The concentrations of protein, phosphorus $(\mathrm{P})$, potassium $(\mathrm{K})$, sulfur $(\mathrm{S})$, calcium (Ca), and magnesium (Mg) in mothbean seeds varied from $19 \%$ to $24 \%, 0.25 \%$ to $0.33 \%, 1.17 \%$ to $1.41 \%, 0.17 \%$ to $0.20 \%, 0.15 \%$ to $0.20 \%$, and $0.18 \%$ to $0.25 \%$, respectively (Table 4 ) with respective means being $22 \%, 0.29 \%, 1.31 \%, 0.18 \%, 0.17 \%$, and $0.21 \%$. The concentrations of iron $(\mathrm{Fe})$, manganese $(\mathrm{Mn})$, copper $(\mathrm{Cu})$, zinc $(\mathrm{Zn})$, and boron (B) for all 30 accessions tested varied from 59 to $79,13.5$ to $53.5,7.2$ to $9.9,34$ to 43 , and 4.8 to $11.5 \mathrm{ppm}$, respectively (Table 4) with respective means being 65,24 , $8.4,38$, and $7.3 \mathrm{ppm}$.

Siddhuraju et al. (1994) indicated that the mean concentration of protein, $\mathrm{P}, \mathrm{K}, \mathrm{Ca}$, and $\mathrm{Mg}$ in seeds from wild mothbean plants from Tamil Nadu state of India were $23 \%$, $0.19 \%, 1.39 \%, 0.35 \%$, and $0.26 \%$, respectively, whereas concentrations of $\mathrm{Fe}, \mathrm{Cu}, \mathrm{Mn}$, and $\mathrm{Zn}$ were $20,1.82$, 3.2 , and $7 \mathrm{ppm}$, respectively. The current study indicated that, in general, mothbean produced in the eastern United States had nutritional quality similar to that reported from India except for concentrations of $\mathrm{Fe}$, $\mathrm{Mn}$, and $\mathrm{Zn}$ which were of higher magnitude in seed produced in the United States. On the other hand, concentration of $\mathrm{Ca}$ in seeds produced in India was greater than that in seeds produced in the United States. However, further investigations are needed to fully explain these comparisons since the current data are from only 1 year and one location.

To characterize nutritional quality of mothbean, concentrations of mothbean mature seeds was compared with that of tepary bean and mungbean (Table 5), two other crops that have been studied in the eastern United States, for protein, P, K, S, Ca, $\mathrm{Mg}, \mathrm{Fe}, \mathrm{Cu}, \mathrm{Zn}$, and $\mathrm{B}$. Our results from mungbean have indicated that this crop is not very drought tolerant. However, tepary bean is an established drought-tolerant crop (Bhardwaj and Hamama, 2004). These results indicated that, in general, mothbean compared well with seed composition data from tepary bean and mungbean. Even though, mean protein concentration in mothbean seeds $(21.9 \%)$ was slightly lower than $23.9 \%$ in tepary bean (Bhardwaj and Hamama, 2004 ) and $24.3 \%$ in mungbean seeds (Bhardwaj and Hamama, 2016), some mothbean accessions had the protein concentration as high as $23.7 \%$ (Table 4). Similar values were observed for several other traits including $\mathrm{Ca}, \mathrm{Fe}$, and $\mathrm{Zn}$ indicating that mothbean nutritional quality may be acceptable. Moreover, these data are from unimproved mothbean accessions, whereas the values for tepary bean and mungbean are from improved cultivars and lines. This indicates that a concerted effort could result in mothbean selections with improved nutritional quality. In this study, concentrations of other nutritional traits (oil and fatty acids, sugars, etc.) were not determined and would need to be characterized through future research efforts. However, anecdotal evidence from India indicates that mothbean is considered a good pulse for human consumption in India.

The mothbean crop in this study had a soil-hugging, viney growth habit and was observed to totally cover the soil. Based on results of this study, we suggest that mothbean may have potential as an alternative, new food legume crop for the eastern and, perhaps, also in other parts of the United States.

\section{Conclusions}

The results, related to seed yields and nutritional quality traits of 54 accessions, demonstrated that 


\section{Preliminary and Regional Reports}

mothbean has considerable potential as an alternative, new food legume crop in Virginia and in the eastern United States.

\section{Literature cited}

AOAC. 1995. Official methods of analysis of the association of official grain legumes. 16th ed. AOAC Intl., Arlington, VA.

Bhardwaj, H.L. and A.A. Hamama. 2004. Protein and mineral composition of tepary bean seed. HortScience 39:1363-1365.

Bhardwaj, H.L. and A.A. Hamama. 2016. Cultivar, planting date, and row spacing effects on mungbean seed composition. J. Agr. Sci. 8:26-32.

Fery, R.L. 2002. New opportunities in Vigna, p. 424-428. In: J. Janick and A Whipkey (eds.). Trends in new crops and new uses. ASHS Press, Alexandria, VA.

Jury, W.A. and H.J. Vaux. 2007. The emerging global water crisis: Managing scarcity and conflict between water users. Adv. Agron. 95:1-76.

Manga, V.K., A.K. Juktani, and R.K. Bhatt. 2015. Adaptation and selection of crop varieties for hot arid climate of Rajasthan. Indian J. Plant Sci. 4:1-9.
National Academy of Sciences. 1979. Tropical legumes: Resources for the future. Natl. Acad. Sci., Washington, DC.

Siddhuraju, P., K. Vijayakumari, and K. Janardhann. 1994. Chemical analysis and nutritional assessment of the less known pulses, Vigna aconitifolia (Jacq.) Marechal and Vigna vexillata (L.) A. Rich. Plant Foods Hum. Nutr. 45:103111.

Stephens, J.M. 1994. Bean, moth: Vigna aconitifolia (Jacq.) Marechal. Univ. Florida, Coop. Ext. Serv., Inst. Food Agr. Sci. HS554. 